\title{
Aspects of the Circular Economy in the Member States of the European Union
}

\author{
By Florina Bran ${ }^{1}$, Dumitru Alexandru Bodislav ${ }^{1}$, Svetlana Platagea Gombos ${ }^{1}$, \\ Petrică Sorin Angheluță ${ }^{1}$
}

\begin{abstract}
The interest in having a low-carbon economy has led to transformations in the economies of all countries. New economic models are being put into practice. New jobs are being created. Sustainable use of resources is becoming more important. The article presents an analysis of waste generation in the member countries of the European Union. The study of the possibility of reusing certain materials started from the design phase of the finished product. Production processes can also contribute to saving natural resources. This can create new business opportunities and avoid inefficient waste management. The article also analyzes the degree of municipal waste collection, as well as the share of recycled municipal waste. In the production process, the recovery of certain materials and then their use can lead to savings in the use of raw materials. This reduces the pressure exerted by the extraction of raw materials on the environment. Further investments in green technologies will contribute to the efficient use of natural resources, restore biodiversity and reduce pollution.
\end{abstract}

Keywords: generation of waste, recycling of waste, European Union

\section{Introduction}

Reducing the impact of waste on the environment is one of the desideratum of this century (Bran et al., 2020). Savings can have sustainable growth based on increasing resource efficiency (Radulescu et al., 2021). This is one of the ways in which waste generated can be reduced in general. Resource efficiency can also lead to reduced greenhouse gas emissions. Environmental degradation is caused by global warming and climate change (Radulescu et al., 2020). The circular economy contributes to the efficiency of waste management (Bodislav et al., 2019). Thus, the reuse in the production process of certain categories of waste can lead to a decrease in the impact they have on the environment (Negescu Oancea, et al., 2020).

It is estimated that by 2050 the amount of waste will increase to 3,4 billion tons (billion tons). Of this amount, approximately $44 \%$ will be food/green, $17 \%$ paper/cardboard, $12 \%$ plastic, 5\% glass, and 4\% metal. Also, the Europe and Central Asia area will generate 392 million tons annually (WB, 2018).

It is hoped that economic growth will not be based on increasing resource consumption (Jianu et al., 2019). It is also desired that the products made by enterprises become more and more sustainable (EC, 2020).

The need to achieve sustainable products and services can lead to the emergence of new business models(Sarbu et al., 2021). Based on upgrading knowledge and skills, these new 
models can lead to the creation of new jobs (Burlacu et al., 2019). The sustainability of such models aims to avoid waste generation (Angheluta et al., 2019). The use of secondary raw materials in the production flow can lead to a reduction in the amount of final waste(Profiroiu et al., 2020). Responsible consumption and production cannot be addressed without taking into account the issues related to the circular economy (Profiroiu et al., 2020).

One of the important aspects of sustainable development is the physical flows of energy and materials. Thus, in terms of volume and size, there is a decrease in the global natural ecosystem. Earth-sustaining functions can no longer be provided by terrestrial ecosystems due to their declining qualitative potential (Korhonen et al., 2018a).

\section{Literature Review}

Over time, the concept of circular economy has been used in various forms of sustainability, such as: Ecodesign, Closed-Loop-Supply Chain Management, eco-efficiency and Cleaner Production, industrial Ecology (Reike et al., 2018). The way in which the problems related to waste and waste were approached led to the idea of circularity.

The idea of circular economy is found in different types of organizations and in various fields of activity. It is important that the transformation from a wasteful and linear structure into a reproductive, restorative and cyclical structure leads, in the short and long term, to a more sustainable global society (Korhonen et al., 2018b). The concept of circular economy has had different interpretations. Thus, it can be considered as an economic system that refers to a recovery, recycling, reuse of materials in all phases of production, distribution and consumption (Kirchherr et al., 2017).

At the level of the European Union there is a certain interest in the circular economy. Thus, the circular economy package provides for concrete actions that envisage a complete cycle, from production to consumption. Issues related to the waste generated as well as to the raw materials used are also mentioned (EEA, 2016).

The consumption of primary resources could be more efficient by applying the concept of circular economy. Consumption of primary raw materials could be reduced by reusing waste from the production of a product. This waste can thus be considered as secondary raw materials. Such an approach would create new job opportunities.

Natural and material resources are components of a continuous flow that underpin the economies of European Union countries. The volatility of natural resources, as well as their rising price, can put pressure on economies (EEA, 2016).

Only by considering all dimensions of the circular economy (economic, technical, environmental, social), waste can be capitalized as resources (Moraga et al., 2019).

New models of savings lead to changes in technological flows. These changes start right from the design stage. Issues related to the conservation of natural resources as well as the use of waste as secondary resources are also considered. In this way, given this last aspect, the new designed models could be based on secondary resources. Last but not least, the new savings models require changes in consumer behavior. It is found, however, that the link between the circular economy and consumption is increasingly relevant (CamachoOtero et al., 2018).

The use of waste as a secondary raw material can have positive economic effects (OECD, 
2013). Thus, measures are needed to implement standards regarding the ecological design of future products and to increase the efficiency of the materials used (Vanegas et al., 2018). Increasing the efficiency of construction materials and reducing the waste generated by this sector can lead to an $80 \%$ reduction in greenhouse gas emissions (Hertwich et al., 2020).

Another effect of waste recycling is the possibility of reducing greenhouse gas emissions. The transition to the circular economy cannot have uniform benefits. Some businesses or industries have something to lose and others to gain. Obtaining benefits is conditioned by the degree to which those appropriate skills are identified and applied, leading to the circular economy (EEA, 2016).

There are also some fears that the circular economy may not lead to those long-awaited environmental or economic gains. From this point of view, the transition to a sustainable circular economy must take into account the biophysical limitations of circularity (Velenturf et al., 2019).

However, it is considered that human society has the opportunity to find solutions for the waste streams produced to be integrated into nature's own cycles. Thus, waste could be used both for the benefit of the human economy and for the benefit of nature (Korhonen et al., 2018a).

\section{Methodology of Research}

The article presents an analysis of waste generation in the member countries of the European Union. The article also analyzes the degree of municipal waste collection, as well as the share of recycled municipal waste.

\section{Results and Discussions}

It is considered that a harmonization of waste collection systems can lead to a decrease in the amount of municipal waste (EC, 2020).

The following table presents the comparative situation of the quantities of municipal waste generated per capita, for the member countries of the European Union, for the period 2008-2018 (kilograms per capita).

Table 1: Comparative situation of quantities of municipal waste generated per capita, 20082018

\begin{tabular}{|l|c|c|c|c|c|c|c|c|c|c|c|}
\hline Countries & 2008 & 2009 & 2010 & 2011 & 2012 & 2013 & 2014 & 2015 & 2016 & 2017 & 2018 \\
\hline European Union & 518 & 510 & 503 & 499 & 488 & 478 & 478 & 480 & 490 & 495 & 495 \\
\hline Belgium & 480 & 467 & 456 & 455 & 445 & 436 & 425 & 412 & 419 & 411 & 409 \\
\hline Bulgaria & 599 & 598 & 554 & 508 & 460 & 432 & 442 & 419 & 404 & 435 & 407 \\
\hline Czechia & 306 & 317 & 318 & 320 & 308 & 307 & 310 & 316 & 339 & 489 & 494 \\
\hline Denmark & 830 & 762 & $:$ & 862 & 806 & 813 & 808 & 822 & 830 & 820 & 814 \\
\hline Germany & 589 & 592 & 602 & 626 & 619 & 615 & 631 & 632 & 633 & 627 & 606 \\
\hline Estonia & 392 & 339 & 305 & 301 & 280 & 293 & 357 & 359 & 376 & 390 & 405 \\
\hline Ireland & 718 & 651 & 624 & 616 & 585 & $:$ & 562 & $:$ & 581 & 576 & 598 \\
\hline Greece & 458 & 464 & 532 & 503 & 495 & 482 & 488 & 488 & 498 & 504 & 515 \\
\hline Spain & 551 & 542 & 510 & 485 & 468 & 454 & 448 & 456 & 463 & 473 & 475 \\
\hline
\end{tabular}




\begin{tabular}{|l|c|c|c|c|c|c|c|c|c|c|c|}
\hline Countries & 2008 & 2009 & 2010 & 2011 & 2012 & 2013 & 2014 & 2015 & 2016 & 2017 & 2018 \\
\hline France & 538 & 534 & 534 & 534 & 527 & 520 & 517 & 516 & 530 & 535 & 535 \\
\hline Croatia & 415 & 405 & 379 & 384 & 391 & 404 & 387 & 393 & 403 & 416 & 432 \\
\hline Italy & 552 & 543 & 547 & 529 & 504 & 491 & 488 & 486 & 497 & 488 & 501 \\
\hline Cyprus & 729 & 729 & 695 & 676 & 664 & 618 & 602 & 620 & 633 & 625 & 646 \\
\hline Latvia & 345 & 352 & 324 & 350 & 323 & 350 & 364 & 404 & 410 & 411 & 407 \\
\hline Lithuania & 428 & 381 & 404 & 442 & 445 & 433 & 433 & 448 & 444 & 455 & 464 \\
\hline Luxembourg & 697 & 679 & 679 & 666 & 652 & 616 & 626 & 607 & 815 & 798 & 803 \\
\hline Hungary & 454 & 430 & 403 & 382 & 402 & 378 & 385 & 377 & 379 & 385 & 381 \\
\hline Malta & 674 & 649 & 601 & 589 & 590 & 579 & 591 & 640 & 641 & 666 & 663 \\
\hline Netherlands & 600 & 589 & 571 & 568 & 549 & 526 & 527 & 523 & 520 & 513 & 511 \\
\hline Austria & 600 & 590 & 562 & 573 & 579 & 578 & 565 & 560 & 564 & 570 & 579 \\
\hline Poland & 320 & 316 & 316 & 319 & 317 & 297 & 272 & 286 & 307 & 307 & 315 \\
\hline Portugal & 518 & 520 & 516 & 490 & 453 & 440 & 453 & 460 & 474 & 486 & 507 \\
\hline Romania & 411 & 381 & 313 & 259 & 251 & 254 & 249 & 247 & 261 & 272 & 272 \\
\hline Slovenia & 542 & 524 & 490 & 415 & 362 & 414 & 432 & 449 & 457 & 471 & 486 \\
\hline Slovakia & 313 & 307 & 319 & 311 & 306 & 304 & 320 & 329 & 348 & 378 & 414 \\
\hline Finland & 521 & 480 & 470 & 505 & 506 & 493 & 482 & 500 & 504 & 510 & 551 \\
\hline Sweden & 485 & 472 & 441 & 453 & 454 & 455 & 443 & 451 & 447 & 452 & 434 \\
\hline
\end{tabular}

Source: processing according to data published by EUROSTAT, 2021

From the data presented in the table, it is observed that in 2018, compared to 2008, the amount of municipal waste generated in kilograms per capita increased in: Czechia $(+188$ kilograms per capita), Luxembourg (+106 kilograms per capita), Slovenia (+101 kilograms per capita), Latvia (+62 kilograms per capita), Greece ( +57 kilograms per capita). Also, for the same period, the amount of municipal waste generated in kilograms per capita decreased in the following countries: Bulgaria (-192 kilograms per capita), Romania (-139 kilograms per capita), Ireland (-120 kilograms per capita), Netherlands (-89 kilograms per capita), Cyprus (-83 kilograms per capita). In 2018, the highest amounts of municipal waste generated in kilograms per capita were recorded in: Denmark (814 kilograms per capita), Luxembourg (803 kilograms per capita), Malta (663 kilograms per capita), Cyprus (646 kilograms per capita), Germany (606 kilograms per capita), Ireland (598 kilograms per capita), Austria (579 kilograms per capita). Also, the smallest quantities were generated in: Romania (272 kilograms per capita), Poland (315 kilograms per capita), Hungary (381 kilograms per capita), Estonia (405 kilograms per capita), Bulgaria (407 kilograms per capita), Latvia (407 kilograms per capita).

The following graph, for the period 2008-2018, shows the evolution of the amount of municipal waste generated in kilograms per capita in the European Union. 


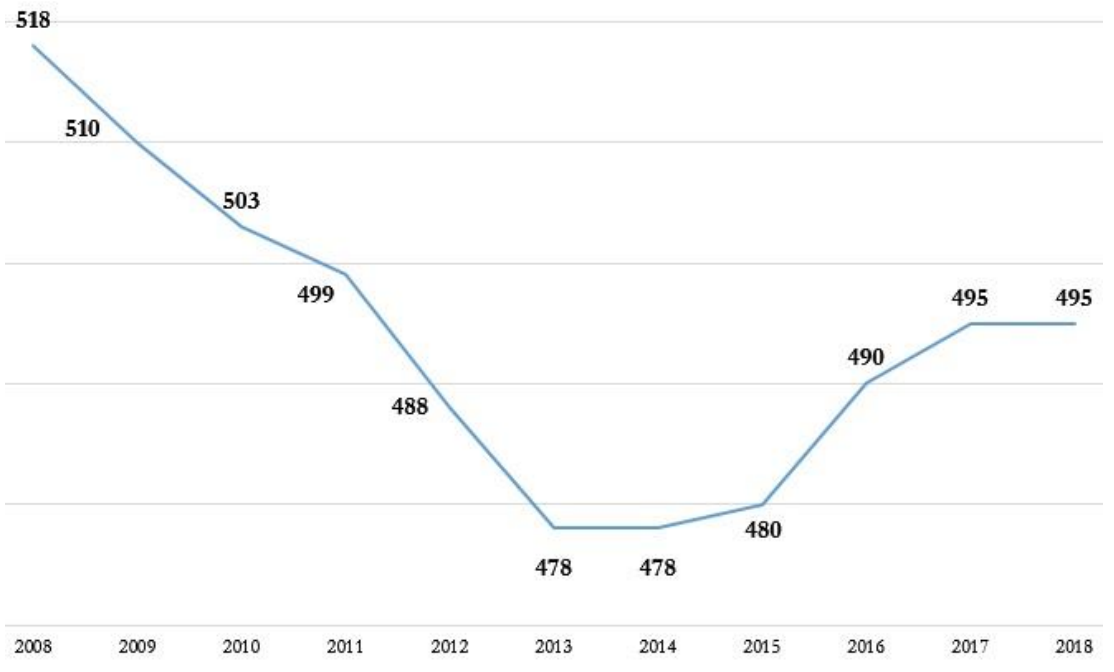

Figure 1: Evolution of the amount of municipal waste generated in kilograms per capita, 2008-2018 Source: processing according to data published by EUROSTAT, 2021

At European level, in 2018, compared to 2008, the amount of municipal waste generated in Kilograms per capita decreased by 23 kilograms (from 518 Kilograms per capita to 495 Kilograms per capita). It is observed that in the period 2008-2013 the values decreased, and in the following period, until 2018, the values increased.

The following table presents the comparative situation of generation of waste (excluding major mineral wastes per domestic material consumption), for the period 2004-2018 (\%).

Table 2: Comparative situation of generation of waste (excluding major mineral wastes per domestic material consumption), 2004-2018, (\%)

\begin{tabular}{|l|c|c|c|c|c|c|c|c|}
\hline Countries & 2004 & 2006 & 2008 & 2010 & 2012 & 2014 & 2016 & 2018 \\
\hline European Union & 11,0 & 10,8 & 10,2 & 11,9 & 12,2 & 12,6 & 12,9 & 12,7 \\
\hline Belgium & 20,9 & 20,8 & 14,8 & 25,0 & 20,5 & 23,1 & 25,4 & 26,4 \\
\hline Bulgaria & 13,4 & 10,4 & 11,2 & 12,3 & 14,0 & 13,1 & 13,3 & 15,2 \\
\hline Czechia & 9,3 & 6,7 & 6,4 & 7,4 & 8,0 & 7,3 & 7,8 & 9,7 \\
\hline Denmark & 5,9 & 5,6 & 6,3 & 9,0 & 7,4 & 8,2 & 7,1 & 7,4 \\
\hline Germany & 9,1 & 9,0 & 9,8 & 11,1 & 11,0 & 11,5 & 12,2 & 12,1 \\
\hline Estonia & 49,9 & 36,1 & 31,2 & 34,5 & 31,8 & 33,6 & 33,3 & 29,7 \\
\hline Ireland & 3,3 & 3,0 & 1,7 & 11,9 & 9,1 & 8,4 & 8,1 & 6,6 \\
\hline Greece & 15,5 & 16,7 & 10,0 & 12,7 & 15,6 & 15,1 & 11,4 & 13,3 \\
\hline Spain & 9,7 & 8,4 & 8,7 & 10,5 & 15,6 & 16,9 & 17,2 & 16,4 \\
\hline France & 10,5 & 10,5 & 10,6 & 12,4 & 12,6 & 12,3 & 13,3 & 13,0 \\
\hline Croatia & 8,6 & 8,1 & 4,8 & 6,9 & 6,5 & 7,9 & 8,4 & 8,8 \\
\hline Italy & 10,1 & 10,5 & 11,8 & 14,5 & 17,2 & 21,4 & 22,5 & 22,9 \\
\hline Cyprus & 10,5 & 4,9 & 2,6 & 3,7 & 4,0 & 5,4 & 5,4 & 5,2 \\
\hline Latvia & 5,5 & 6,1 & 4,7 & 6,6 & 7,9 & 8,3 & 6,4 & 4,8 \\
\hline Lithuania & 16,2 & 13,7 & 10,8 & 7,9 & 7,8 & 7,5 & 7,9 & 7,9 \\
\hline Luxembourg & 10,2 & 10,7 & 10,0 & 14,0 & 11,9 & 7,6 & 11,4 & 10,0 \\
\hline
\end{tabular}




\begin{tabular}{|l|c|c|c|c|c|c|c|c|}
\hline Countries & 2004 & 2006 & 2008 & 2010 & 2012 & 2014 & 2016 & 2018 \\
\hline Hungary & 12,0 & 10,7 & 9,0 & 11,8 & 13,1 & 9,4 & 9,2 & 7,0 \\
\hline Malta & 8,1 & 8,3 & 12,3 & 11,4 & 8,9 & 8,0 & 9,3 & 8,4 \\
\hline Netherlands & 22,2 & 22,5 & 20,9 & 22,9 & 23,8 & 24,5 & 25,6 & 27,9 \\
\hline Austria & 13,8 & 13,0 & 13,5 & 9,9 & 8,8 & 9,6 & 9,8 & 9,9 \\
\hline Poland & 10,8 & 10,9 & 9,3 & 10,3 & 10,2 & 11,5 & 11,8 & 10,9 \\
\hline Portugal & 9,7 & 11,6 & 6,0 & 5,7 & 6,7 & 7,3 & 7,7 & 8,1 \\
\hline Romania & 13,2 & 13,6 & 10,3 & 8,6 & 6,5 & 5,6 & 4,7 & 4,8 \\
\hline Slovenia & 11,2 & 9,2 & 8,1 & 11,6 & 13,6 & 12,2 & 11,4 & 10,3 \\
\hline Slovakia & 10,2 & 13,1 & 10,5 & 9,2 & 10,5 & 9,3 & 11,8 & 11,7 \\
\hline Finland & 12,4 & 12,9 & 11,1 & 13,1 & 11,8 & 8,1 & 8,2 & 7,4 \\
\hline Sweden & 12,9 & 12,8 & 11,2 & 9,0 & 8,5 & 8,1 & 9,2 & 8,7 \\
\hline
\end{tabular}

Source: processing according to data published by EUROSTAT, 2021

It is observed that in 2018, compared to 2004, the share of generation of waste (excluding major mineral wastes per domestic material consumption) increased in: Italy $(+12,8 \%)$, Spain $(+6,7 \%)$, Netherlands $(+5,7 \%)$, Belgium $(+5,5 \%)$, Ireland $(+3,3 \%)$, Germany $(+3,0 \%)$, France $(+2,5 \%)$. Also, the values in 2018 were lower than in 2004 in: Estonia ($20,2 \%)$, Romania $(-8,4 \%)$, Lithuania $(-8,3 \%)$, Cyprus $(-5,3) \%)$, Hungary $(-5,0 \%)$, Finland $(-5,0 \%)$, Sweden $(-4,2 \%)$, Austria $(-3,9 \%)$, Greece $(-2,2 \%)$, Portugal $(-1,6 \%)$. For 2018 , the highest shares of waste generation were registered in: Estonia $(29,4)$, Netherlands $(27,9)$, Belgium (26,4), Italy (22,9), Spain (16,4), Bulgaria $(15,2)$. At the same time, the lowest values are observed for: Romania (4,8\%), Latvia (4,8\%), Cyprus (5,2\%), Ireland (6,6\%), Hungary $(7,0 \%)$, Finland $(7,4 \%)$, Denmark (7,4\%), Portugal $(8,1 \%)$,

At European level, the following figure shows the evolution of waste generation (excluding major mineral wastes per domestic material consumption), for the period 2004-2018 (\%).

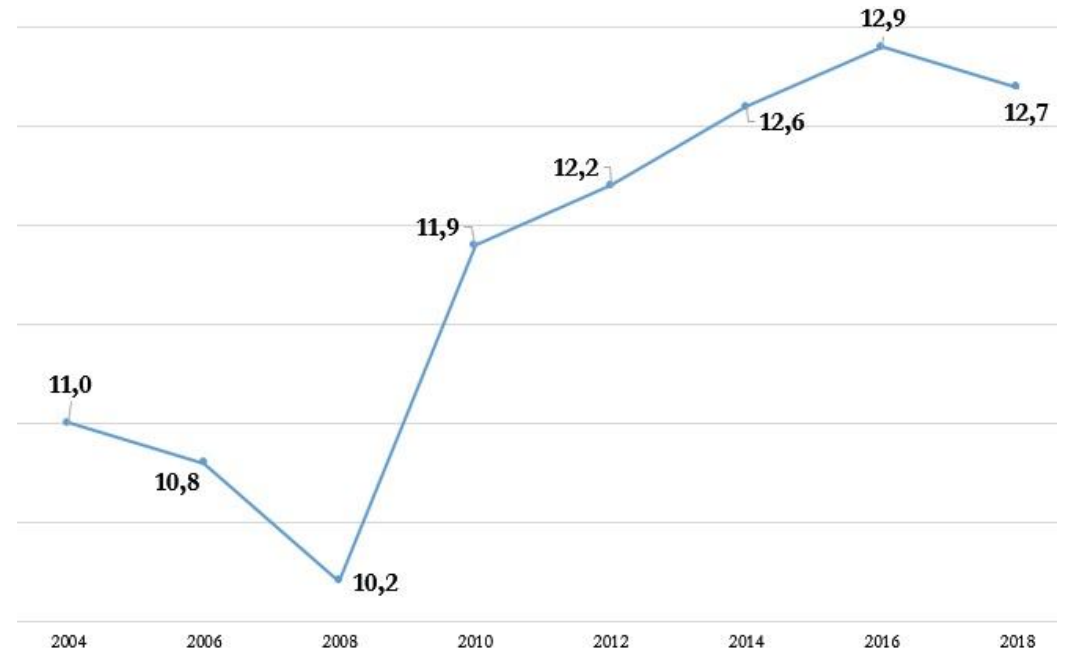

Figure 2: Evolution of waste generation (excluding major mineral wastes per domestic material consumption), 2004 2018

Source: processing according to data published by EUROSTAT, 2021 
From the previous figure, it is observed that in the period 2004-2008 there was a decrease in the share of generation of waste (excluding major mineral wastes per domestic material consumption). For this indicator, the period 2008-2016 showed an increase in values (from $10,2 \%$ to $12,9 \%$ ). Also, for the period 2016-2018 there is a decreasing trend (from 12,9\% to $12,7 \%$ ).

Another important indicator is the recycling rate of all waste. The following table presents the comparative situation of the recycling rate of all waste (excluding major mineral waste), for the period 2010-2018.

Table 3: Comparative situation of recycling rate of all waste (excluding major mineral waste), 2008-2018

\begin{tabular}{|l|c|c|c|c|c|}
\hline Countries & 2010 & 2012 & 2014 & 2016 & 2018 \\
\hline European Union & 53 & 53 & 54 & 55 & 55 \\
\hline Belgium & 75 & 80 & 81 & 78 & 81 \\
\hline Bulgaria & 27 & 14 & 17 & 27 & 23 \\
\hline Czechia & 50 & 58 & 60 & 60 & 61 \\
\hline Denmark & 56 & 59 & 60 & 61 & 59 \\
\hline Germany & 55 & 54 & 53 & $:$ & 53 \\
\hline Estonia & 22 & 25 & 19 & 10 & $:$ \\
\hline Ireland & 36 & 37 & 45 & 41 & 41 \\
\hline Greece & $:$ & $:$ & $:$ & $:$ & $:$ \\
\hline Spain & 44 & 46 & 46 & 46 & 47 \\
\hline France & 50 & 51 & 53 & 54 & 52 \\
\hline Croatia & 26 & 35 & 47 & 52 & 56 \\
\hline Italy & 60 & 64 & 67 & 68 & 67 \\
\hline Cyprus & 46 & 34 & 31 & 31 & 32 \\
\hline Latvia & $:$ & $:$ & $:$ & $:$ & 50 \\
\hline Lithuania & 50 & 51 & 57 & 68 & 72 \\
\hline Luxembourg & 87 & 77 & 62 & 64 & 70 \\
\hline Hungary & 36 & 35 & 40 & 43 & 49 \\
\hline Malta & 24 & 28 & 27 & 43 & 28 \\
\hline Netherlands & 71 & 71 & 72 & 72 & 66 \\
\hline Austria & 60 & 65 & 62 & 66 & 63 \\
\hline Poland & 58 & 55 & 60 & 56 & 58 \\
\hline Portugal & 47 & 49 & 54 & 52 & 54 \\
\hline Romania & 26 & 28 & 27 & 30 & 29 \\
\hline Slovenia & 52 & 74 & 75 & 80 & 82 \\
\hline Slovakia & 38 & 40 & 40 & 44 & 50 \\
\hline Finland & 53 & 41 & 41 & 37 & 37 \\
\hline Sweden & 53 & 51 & 49 & 50 \\
\hline
\end{tabular}

Source: processing according to data published by EUROSTAT, 2021

It is observed that in 2018, compared to 2010, the share of recycling rate of all waste (excluding major mineral waste) increased for: Croatia $(+30 \%)$, Slovenia $(+30 \%)$, Lithuania $(+22 \%)$, Hungary $(+13 \%)$, Slovakia $(+12 \%)$, Czechia $(+11 \%)$. Decreases in values were recorded in: Luxembourg (-17\%), Cyprus (-14\%), Netherlands (-5\%), Bulgaria $(-4 \%)$, Germany $(-2 \%)$, Sweden $(-1 \%)$. 
Of the entire amount of waste recycled, it is important to recycle municipal waste. The following table presents the comparative situation of the recycling rate of municipal waste for the period 2008-2018 (thousand tons).

Table 4: Comparative situation of recycling rate of municipal waste, 2008-2018

\begin{tabular}{|c|c|c|c|c|c|c|c|c|c|c|c|}
\hline Countries & 2008 & 2009 & 2010 & 2011 & 2012 & 2013 & 2014 & 2015 & 2016 & 2017 & 2018 \\
\hline European Union & 36,5 & 37,3 & 38,0 & 38,9 & 40,9 & 41,5 & 43,4 & 44,9 & 46,5 & 47,0 & 47,2 \\
\hline Belgium & 52,7 & 53,9 & 54,8 & 54,4 & 53,4 & 52,8 & 53,8 & 53,5 & 53,5 & 53,9 & 54,4 \\
\hline Bulgaria & 19,4 & 19,9 & 24,5 & 26,2 & 25,0 & 28,5 & 23,1 & 29,4 & 31,8 & 34,6 & 31,5 \\
\hline Czechia & 10,4 & 12,4 & 15,8 & 17,0 & 23,2 & 24,2 & 25,4 & 29,7 & 33,6 & 32,0 & 32,2 \\
\hline Denmark & 47,9 & 48,8 & : & 42,4 & 42,5 & 43,3 & 45,4 & 47,4 & 48,3 & 47,6 & 49,9 \\
\hline Germany & 63,8 & 63,1 & 62,5 & 63,0 & 65,2 & 63,8 & 65,6 & 66,7 & 67,1 & 67,2 & 67,1 \\
\hline Estonia & 20,2 & 21,0 & 18,2 & 23,3 & 19,1 & 17,9 & 31,3 & 28,3 & 28,1 & 28,4 & 28,0 \\
\hline Ireland & 33,6 & 33,5 & 35,7 & 36,1 & 36,6 & : & 39,8 & 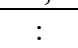 & 40,7 & 40,4 & 37,6 \\
\hline Greece & 17,7 & 18,9 & 17,1 & 17,8 & 17,0 & 15,8 & 15,4 & 15,8 & 17,2 & 18,9 & 20,1 \\
\hline Spain & 39,7 & 33,2 & 29,2 & 26,7 & 29,8 & 32,5 & 30,8 & 30,0 & 33,9 & 36,1 & 34,8 \\
\hline France & 33,8 & 35,3 & 36,0 & 36,8 & 37,7 & 38,7 & 39,7 & 40,7 & 42,9 & 44,1 & 45,1 \\
\hline Croatia & 2,8 & 2,3 & 4,0 & 8,3 & 14,7 & 14,9 & 16,5 & 18,0 & 21,0 & 23,6 & 25,3 \\
\hline Italy & 23,8 & 29,7 & 31,0 & 35,5 & 38,4 & 39,4 & 41,6 & 44,3 & 45,9 & 47,8 & 49,8 \\
\hline Cyprus & 7,5 & 8,3 & 10,9 & 11,0 & 12,5 & 13,9 & 14,8 & 16,6 & 16,1 & 16,2 & 16,5 \\
\hline Latvia & 6,4 & 7,7 & 9,4 & 9,7 & 14,7 & 25,9 & 27,0 & 28,7 & 25,2 & 24,8 & 25,2 \\
\hline Lithuania & 8,5 & 8,5 & 4,9 & 19,9 & 23,5 & 27,8 & 30,5 & 33,1 & 48,0 & 48,1 & 52,5 \\
\hline Luxembourg & 46,0 & 46,2 & 46,5 & 46,4 & 47,4 & 46,6 & 47,7 & 47,4 & 49,2 & 48,7 & 49,0 \\
\hline Hungary & 15,2 & 15,4 & 19,6 & 22,0 & 25,5 & 26,4 & 30,5 & 32,2 & 34,7 & 35,0 & 37,4 \\
\hline Malta & 3,6 & 3,7 & 5,2 & 9,0 & 9,7 & 8,5 & 7,4 & 10,9 & 12,3 & 10,9 & 10,0 \\
\hline Netherlands & 48,4 & 49,1 & 49,2 & 49,1 & 49,4 & 49,8 & 50,9 & 51,8 & 53,5 & 54,6 & 55,9 \\
\hline Austria & 63,2 & 61,9 & 59,4 & 56,7 & 57,7 & 57,7 & 56,3 & 56,9 & 57,6 & 57,7 & 57,7 \\
\hline Poland & 10,5 & 13,2 & 16,3 & 11,4 & 12,0 & 15,1 & 26,5 & 32,5 & 34,8 & 34,8 & 33,8 \\
\hline Portugal & 17,3 & 19,5 & 18,7 & 20,1 & 26,1 & 25,8 & 30,4 & 29,8 & 30,9 & 29,1 & 29,1 \\
\hline Romania & 0,9 & 1,1 & 12,8 & 11,7 & 14,8 & 13,2 & 13,1 & 13,2 & 13,4 & 14,0 & 11,1 \\
\hline Slovenia & 18,9 & 19,6 & 22,4 & 35,6 & 41,9 & 34,8 & 36,0 & 54,1 & 55,6 & 57,8 & 58,9 \\
\hline Slovakia & 7,4 & 8,2 & 9,1 & 10,8 & 13,4 & 10,8 & 10,3 & 14,9 & 23,0 & 29,8 & 36,3 \\
\hline Finland & 34,3 & 35,9 & 32,8 & 34,8 & 33,3 & 32,5 & 32,5 & 40,6 & 42,0 & 40,5 & 42,3 \\
\hline Sweden & 45,6 & 49,2 & 47,8 & 47,0 & 46,9 & 48,2 & 49,3 & 47,5 & 48,4 & 46,8 & 45,8 \\
\hline
\end{tabular}

Source: processing according to data published by EUROSTAT, 2021

From the data presented, it is observed that the recycling rate of municipal waste increased in 2018 compared to 2008 for: Lithuania ( $+44,0$ thousand tons), Slovenia ( $+40,0$ thousand tons), Slovakia ( $+28,9$ thousand tons), Italy ( $+26,0$ thousand tons), Poland $(+23,3$ thousand tons), Croatia ( $+22,5$ thousand tons), Hungary ( $+22,2$ thousand tons), Czechia $(+21,8$ thousand tons). Also, the values of this indicator decreased for: Austria $(-5,5$ thousand tons) and Spain (-4,9 thousand tons).

In 2018, the countries where the recycling rate of municipal waste was the highest are: Germany (67,1 thousand tons), Slovenia (58,9 thousand tons), Austria (57,7 thousand tons), Netherlands (55, 9 thousand tons), Belgium (54,4 thousand tons), Lithuania (52,5 thousand tons). At the same time, low values were registered in: Malta (10,0 thousand 
tons), Romania (11,1 thousand tons), Cyprus (16,5 thousand tons), Greece (20,1 thousand tons), Latvia (25,2 thousand tons), Croatia (25,3 thousand tons), Estonia (28,0 thousand tons), Portugal (29,1 thousand tons).

The evolution of the recycling rate of municipal waste, for the period 2008-2018, at European level is presented in the following figure.

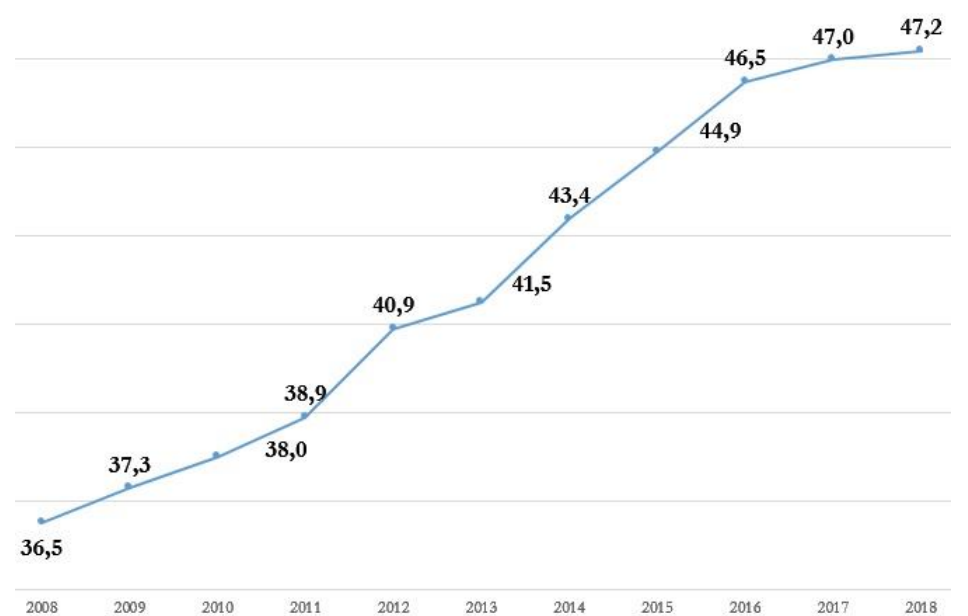

Figure 3: Evolution of recycling rate of municipal waste, 2008-2018

Source: processing according to data published by EUROSTAT, 2021

For the analyzed period, the recycling rate of municipal waste increased from 36.5 thousand tons to 47.2 thousand tons. The trend is upward.

For the circular economy of major importance is also the recycling of biowaste. The following table presents the comparative situation of recycling of biowaste, for the period 2008-2018 (kilograms per capita).

Table 5: Comparative situation of recycling of biowaste, 2008-2018

\begin{tabular}{|l|c|c|c|c|c|c|c|c|c|c|c|}
\hline Countries & 2008 & 2009 & 2010 & 2011 & 2012 & 2013 & 2014 & 2015 & 2016 & 2017 & 2018 \\
\hline European Union & 69 & 67 & 66 & 66 & 69 & 71 & 73 & 75 & 82 & 85 & 84 \\
\hline Belgium & 98 & 95 & 97 & 93 & 93 & 92 & 87 & 80 & 85 & 81 & 82 \\
\hline Bulgaria & 0 & 0 & 0 & 11 & 13 & 15 & 8 & 43 & 37 & 34 & 7 \\
\hline Czechia & 5 & 5 & 7 & 7 & 8 & 9 & 9 & 13 & 23 & 50 & 50 \\
\hline Denmark & 114 & 134 & $:$ & 121 & 125 & 130 & 141 & 151 & 153 & 154 & 143 \\
\hline Germany & 98 & 102 & 101 & 106 & 110 & 106 & 114 & 114 & 116 & 114 & 109 \\
\hline Estonia & 21 & 32 & 24 & 27 & 14 & 15 & 17 & 13 & 10 & 14 & 15 \\
\hline Ireland & 24 & 19 & 23 & 34 & 34 & $:$ & 39 & $:$ & 40 & 51 & 50 \\
\hline Greece & 9 & 3 & 13 & 14 & 16 & 17 & 15 & 12 & 17 & 21 & 26 \\
\hline Spain & 134 & 97 & 59 & 49 & 48 & 77 & 62 & 53 & 72 & 84 & 80 \\
\hline France & 82 & 85 & 85 & 86 & 87 & 89 & 91 & 93 & 104 & 106 & 108 \\
\hline Croatia & 3 & 3 & 3 & 3 & 6 & 7 & 8 & 7 & 7 & 9 & 12 \\
\hline Italy & 53 & 59 & 67 & 67 & 73 & 72 & 80 & 86 & 94 & 98 & 105 \\
\hline Cyprus & 0 & 0 & 0 & 0 & 8 & 9 & 19 & 21 & 19 & 9 & 11 \\
\hline Latvia & 3 & 1 & 2 & 4 & 6 & 20 & 13 & 24 & 42 & 29 & 25 \\
\hline
\end{tabular}




\begin{tabular}{|l|c|c|c|c|c|c|c|c|c|c|c|}
\hline Countries & 2008 & 2009 & 2010 & 2011 & 2012 & 2013 & 2014 & 2015 & 2016 & 2017 & 2018 \\
\hline Lithuania & 5 & 5 & 6 & 8 & 17 & 32 & 41 & 46 & 104 & 109 & 131 \\
\hline Luxembourg & 138 & 135 & 133 & 120 & 128 & 111 & 121 & 111 & 167 & 153 & 154 \\
\hline Hungary & 8 & 9 & 15 & 18 & 18 & 19 & 24 & 23 & 30 & 32 & 32 \\
\hline Malta & 0 & 0 & 0 & 7 & 12 & 0 & 0 & 0 & 0 & 0 & 0 \\
\hline Netherlands & 142 & 145 & 139 & 141 & 140 & 137 & 143 & 143 & 144 & 144 & 147 \\
\hline Austria & 202 & 186 & 182 & 188 & 196 & 192 & 175 & 175 & 181 & 182 & 187 \\
\hline Poland & 10 & 4 & 5 & 6 & 5 & 6 & 15 & 17 & 21 & 21 & 22 \\
\hline Portugal & 36 & 40 & 38 & 42 & 66 & 57 & 64 & 72 & 79 & 83 & 86 \\
\hline Romania & 0 & 0 & 32 & 22 & 29 & 23 & 20 & 18 & 18 & 18 & 9 \\
\hline Slovenia & 8 & 10 & 11 & 22 & 21 & 28 & 30 & 34 & 69 & 73 & 79 \\
\hline Slovakia & 12 & 12 & 11 & 13 & 15 & 13 & 17 & 24 & 26 & 33 & 39 \\
\hline Finland & 44 & 57 & 62 & 66 & 60 & 67 & 70 & 62 & 65 & 67 & 72 \\
\hline Sweden & 57 & 60 & 60 & 64 & 65 & 69 & 72 & 70 & 72 & 70 & 69 \\
\hline
\end{tabular}

Source: processing according to data published by EUROSTAT, 2021

It is noted that in 2018 compared to 2008, only for four countries the values decreased: Spain (-54 kilograms per capita), Belgium (-16 kilograms per capita), Austria (-15 kilograms per capita), Estonia (-6 kilograms per capita). The highest increases were also recorded in: Lithuania (+126 kilograms per capita), Slovenia (+71 kilograms per capita), Italy (+52 kilograms per capita), Portugal (+50 kilograms per capita), Czechia ( +45 kilograms per capita). In 2018, the lowest quantities of recycled biowaste were recorded in: Bulgaria (7 kilograms per capita), Romania (9 kilograms per capita), Cyprus (11 kilograms per capita), Croatia (12 kilograms per capita), Estonia (15 kilograms per capita). At the same time, the largest quantities of biowaste were recycled in: Austria (187 kilograms per capita), Luxemborug (154 kilograms per capita), Netherlands (147 kilograms per capita), Denmark (143 kilograms per capita), Lithuania (131 kilograms per capita) per capita), Germany (109 kilograms per capita), France (108 kilograms per capita), Italy (105 kilograms per capita). At European level, in 2017 compared to 2008, there is an increase of 15 kilograms per capita in the quantities of recycled biowaste. The evolution is shown in the following figure.

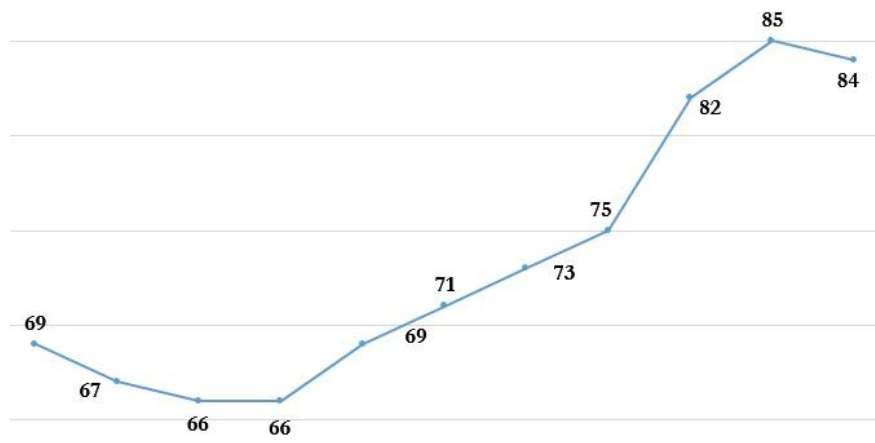

$\begin{array}{llllllllll}2008 & 2009 & 2010 & 2011 & 2012 & 2013 & 2014 & 2015 & 2016 & 2017\end{array}$

Figure 4: Evolution of recycling of biowaste, 2008-2018

Source: processing according to data published by EUROSTAT, 2021 
Another important indicator for the circular economy is circular material use rate. For the period 2010-2018, the comparative situation is presented in the following table $(\%)$.

Thus, compared to 2010, in 2018 circular material use rate increased in: Italy $(+7,3 \%)$, Belgium ( $+6,9 \%)$, Estonia $(+4,7 \%)$, Austria $(+4,5 \%)$, Slovenia $(+4,1 \%)$. Also, circular material use rate decreased in: Luxembourg (-13,3\%), Finland (-7,6\%), Romania (-2,0\%), Spain (-1,1\%), Poland (- 1,0\%), Sweden (-0,6\%), Slovakia (-0,2\%), Ireland (-0,1\%). In 2018, the lowest values were registered in: Romania (1,5\%), Ireland $(1,6 \%)$, Portugal $(2,2 \%)$, Bulgaria (2,5\%), Cyprus (2,8\%), Greece (3,3\%). At the same time, high rates were in: Netherlands (28,9\%), Belgium (19,9\%), France (19,5\%), Italy (18,8\%), Estonia (13,5\%), Germany (11,7\%), Austria (11,1\%), Luxembourg (10,8\%), Slovenia (10,0\%),

Table 6: Comparative situation of circular material use rate, 2010-2018, (\%)

\begin{tabular}{|l|c|c|c|c|c|c|c|c|c|}
\hline Countries & 2010 & 2011 & 2012 & 2013 & 2014 & 2015 & 2016 & 2017 & 2018 \\
\hline European Union & 10,7 & 10,2 & 11 & 11,2 & 11,1 & 11,2 & 11,4 & 11,4 & 11,5 \\
\hline Belgium & 13 & 14 & 16,9 & 16,8 & 17,6 & 17,7 & 17,6 & 18,5 & 19,9 \\
\hline Bulgaria & 2,1 & 1,8 & 1,9 & 2,5 & 2,7 & 3,1 & 4,4 & 3,5 & 2,5 \\
\hline Czechia & 5,3 & 5,4 & 6,3 & 6,7 & 6,8 & 6,9 & 7,5 & 7,9 & 8 \\
\hline Denmark & 8 & 7 & 6,4 & 7,7 & 9 & 8,3 & 8 & 7,9 & 8,1 \\
\hline Germany & 11 & 10,4 & 10,7 & 10,9 & 10,8 & 11,5 & 11,6 & 11,3 & 11,7 \\
\hline Estonia & 8,8 & 14,2 & 19,1 & 14,6 & 10,9 & 11,3 & 11,6 & 12,4 & 13,5 \\
\hline Ireland & 1,7 & 2,1 & 1,8 & 1,7 & 2 & 1,9 & 1,7 & 1,7 & 1,6 \\
\hline Greece & 2,7 & 2,2 & 1,9 & 1,8 & 1,4 & 1,9 & 2,3 & 2,8 & 3,3 \\
\hline Spain & 10,4 & 9,8 & 9,8 & 8,9 & 7,7 & 7,5 & 8,2 & 8,9 & 9,3 \\
\hline France & 17,5 & 16,8 & 16,9 & 17,3 & 17,8 & 18,7 & 19,4 & 18,8 & 19,5 \\
\hline Croatia & 1,6 & 2,4 & 3,6 & 3,9 & 4,8 & 4,6 & 4,6 & 5,2 & 5 \\
\hline Italy & 11,5 & 11,6 & 13,9 & 16 & 16,1 & 17,2 & 17,8 & 18,4 & 18,8 \\
\hline Cyprus & 2 & 1,9 & 2 & 2,4 & 2,2 & 2,4 & 2,4 & 2,4 & 2,8 \\
\hline Latvia & 1,2 & 2,9 & 1,3 & 3,8 & 5,3 & 5,3 & 6,5 & 5,4 & 4,7 \\
\hline Lithuania & 3,9 & 3,6 & 3,8 & 3,1 & 3,7 & 4,1 & 4,6 & 4,5 & 4,3 \\
\hline Luxembourg & 24,1 & 20,7 & 18,5 & 15,4 & 11,3 & 9,7 & 7,1 & 10,6 & 10,8 \\
\hline Hungary & 5,3 & 5,4 & 6,1 & 6,2 & 5,4 & 5,8 & 6,5 & 6,9 & 7 \\
\hline Malta & 5,3 & 4,5 & 3,9 & 6,3 & 6,4 & 4,6 & 4,2 & 6,5 & 8,3 \\
\hline Netherlands & 25,3 & 25 & 26,5 & 27,1 & 26,6 & 25,8 & 28,5 & 29,7 & 28,9 \\
\hline Austria & 6,6 & 6,8 & 7,5 & 8,7 & 9,6 & 10,7 & 11,2 & 11,4 & 11,1 \\
\hline Poland & 10,8 & 9,2 & 10,6 & 11,8 & 12,6 & 11,6 & 10,2 & 9,9 & 9,8 \\
\hline Portugal & 1,8 & 1,7 & 2 & 2,5 & 2,4 & 2,1 & 2,1 & 2 & 2,2 \\
\hline Romania & 3,5 & 2,5 & 2,6 & 2,5 & 2,1 & 1,7 & 1,7 & 1,7 & 1,5 \\
\hline Slovenia & 5,9 & 7,6 & 9,3 & 9,3 & 8,5 & 8,6 & 8,7 & 9,8 & 10 \\
\hline Slovakia & 5,1 & 4,8 & 4,1 & 4,6 & 4,8 & 5,1 & 5,3 & 5 & 4,9 \\
\hline Finland & 13,5 & 14 & 15,3 & 10,1 & 7,3 & 6,4 & 5,3 & 5,6 & 5,9 \\
\hline Sweden & 7,2 & 7,6 & 8,2 & 7,2 & 6,4 & 6,7 & 6,8 & 6,7 & 6,6 \\
\hline
\end{tabular}

Source: processing according to data published by EUROSTAT, 2021

Higher values of circular material use rate imply an increase in the share of replacement of raw materials with secondary materials, resulting in the production process. 


\section{Conclusions}

It is hoped that the circular economy will be a path to sustainable development. But high circularity must be based on the sustainability of both the environment and the economy and society. Thus, an assessment of the degree of recirculation of materials is not enough to measure how much resource use has decreased. This is because pollutant emissions or high energy consumption can occur that influence the values of circularity (Corona et al., 2019).

At European level, in 2018, compared to 2008, the amount of municipal waste generated in Kilograms per capita decreased, even if the values differ from one country to another. At the same time, the generation of waste (excluding major mineral wastes per domestic material consumption) has increased. Also, the recycling rate of municipal waste has increased in most countries, and the trend is increasing. At the same time, there is interest in recycling of biowaste. The values of this indicator indicate an increasing trend for most countries.

In order to be able to apply the transition to a sustainable circular economy, it is necessary to carry out an assessment of both the components of the system (individual products) and an assessment of the whole system (the whole economy). Optimal solutions can be identified only by considering the qualitative aspects of materials and by considering a whole life cycle (Haupt \& Hellweg, 2019).

\section{References}

Angheluta, S. P., Burlacu, S., Diaconu, A., \& Curea, C. S. (2019). The Energy from Renewable Sources in the European Union: Achieving the Goals. European Journal of Sustainable Development, 8(5), 57.

Bran, F., Rădulescu, C. V., Bodislav, D. A., \& Burlacu, S. (2020). Environmental risks in the context of globalization. Economic Convergence in European Union, 350.

Burlacu, S., Profiroiu, A., \& Vasilache, P. C. (2019). Impact Of Demography On The Public Finance Of The European Union. Calitatea, 20(S2), 136-138.

Camacho-Otero, J., Boks, C., Pettersen, I.N. (2018). Consumption in the Circular Economy: A Literature Review, Sustainability, 10, 2758.

Corona, B., Shen, L., Reike, D., Carreón, J.R., Worrell, E. (2019). Towards sustainable development through the circular economy-A review and critical assessment on current circularity metrics, Resources, Conservation \& Recycling, 151, 104498.

EC (European Commission) (2020). A new Circular Economy Action Plan. For a cleaner and more competitive Europe. https://eur-lex.europa.eu/legal-content/EN/TXT/?qid=1583933814386 \&uri=COM:2020:98:FIN. Accessed 14/05/2021.

EEA (European Environment Agency) (2016). Circular economy in Europe. Developing the knowledge base, Report No 2/2016.

Eurostat (2021). Database, https://ec.europa.eu/eurostat/web/main.

Haupt, M. \& Hellweg, S. (2019). Measuring the environmental sustainability of a circular economy, Environmental and Sustainability Indicators, 1-2, 100005.

Hertwich, E., Lifset, R., Pauliuk, S., Heeren, N. (2020). Resource Efficiency and Climate Change: Material Efficiency Strategies for a Low-Carbon Future. https://wedocs.unep.org/bitstream/handle $/ 20.500 .11822 / 34351 /$ RECCR.pdf?sequence=1\&isAllowed=y. Accessed 14/05/2021.

Jianu, I., Dobre, I., Bodislav, D. A., Radulescu, C. V., \& Burlacu, S. (2019). The Implications Of Institutional Specificities On The Income Inequalities Drivers In European Union. Economic Computation and Economic Cybernetics Studies and Research, 53(2), 59-76.

Kirchherr, J., Reike, D., Hekkert, M. (2017). Conceptualizing the circular economy: An analysis of 114 definitions, Resources, Conservation \& Recycling, 127, 221-232. 
Korhonen, J., Honkasalo, A., Seppälä, J. (2018a). Circular Economy: The Concept and its Limitations, Ecological Economics, 143, 37-46.

Korhonen, J., Nuur, C., Feldmann, A., Birkie, S.E. (2018b). Circular economy as an essentially contested concept, Journal of Cleaner Production, 175, 544-552.

Moraga, G., Huysveld, S., Mathieux, F., Blengini, G.A., Alaerts, L., Van Acker, K., de Meester, S., Dewulf, J. (2019). Circular economy indicators: What do they measure? Resources, Conservation \& Recycling, 146, $452-461$.

Negescu, M D; Burlacu, S; Mitriță, M; Buzoianu, O C A. Managerial Analysis of Factoring at the International Level Challenges of the Contemporary Society. Proceedings; Cluj-Napoca Vol. 13, Iss. 1, : 99-102. ClujNapoca: Babes Bolyai University. (2020)

OECD (Organisation for Economic Co-operation and Development) (2013). Why new business models matter for green growth, Green paper, 2013/01.

Profiroiu, C. M., Bodislav, D. A., Burlacu, S., \& Rădulescu, C. V. (2020). Challenges of Sustainable Urban Development in the Context of Population Growth. European Journal of Sustainable Development, 9(3), 51-51.

Profiroiu, M. C., Radulescu, C. V., Burlacu, S., \& Guțu, C. (2020). Changes and trends in the development of the world economy. In Competitivitatea și inovarea in economia cunoașterii (pp. 324-330).

Rădulescu, C. V., Burlacu, S., Bodislav, D. A., \& Bran, F. (2020). Entrepreneurial Education in the Context of the Imperative Development of Sustainable Business. European Journal of Sustainable Development, 9(4), 93-93.

Radulescu, C.V.; Ladaru, G.-R.; Burlacu, S.; Constantin, F.; Ioanăș, C.; Petre, I.L. (2021) Impact of the COVID-19 Pandemic on the Romanian Labor Market. Sustainability 2021, 13, 271. https://doi.org/10.3390/su13010271

Reike, D., Vermeulen, W.J.V., Witjes, S. (2018). The circular economy: New or Refurbished as CE 3.0? Exploring Controversies in the Conceptualization of the Circular Economy through a Focus on History and Resource Value Retention Options, Resources, Conservation \& Recycling, 135, 246-264.

Sarbu, R., Alpopi, C., Burlacu, S., \& Diaconu, S. (2021). Sustainable urban development in the context of globalization and the health crisis caused by the covid-19 pandemic. Les Ulis: EDP Sciences. doi:http://dx.doi.org/10.1051/shsconf/20219201043

Vanegas, P., Peeters, J.R., Cattrysse, D., Tecchio, P., Ardente, F., Mathieux, F., Dewulf , W., Duflou, J.R. (2018). Ease of disassembly of products to support circular economy strategies, Resources, Conservation \& Recycling, 135, 323-334.

Velenturf, A.P.M., Archer, S.A., Gomes, H.I., Christgen, B., Lag-Brotons, A.J., Purnell, P. (2019). Circular economy and the matter of integrated resources, Science of the Total Environment, 689, 963-969

WB (World Bank) (2018). What a Waste 2.0: A Global Snapshot of Solid Waste Management to 2050. https://www.worldbank.org/en/news/infographic/2018/09/20/what-a-waste-20-a-globalsnapshot-of-solid-waste-management-to-2050. Accessed 14/05/2021. 